\title{
Influence of Different Plaque Control Methods and Hydrothermal Aging on Structural Properties of Monolithic Zirconia
}

\author{
Farklı Plak Kontrol Yöntemleri ve Hidrotermal Yaşlanmanın \\ Monolitik Zirkonyanın Yapısal Özelliklerine Etkisi \\ (D) Habibe Öztürk Ulusoy ${ }^{1}$, (1) Çağatay Aktaş ${ }^{2}$ \\ ${ }^{1}$ Çanakkale Onsekiz Mart University Faculty of Dentistry, Department of Prosthodontics, Çanakkale, Turkey \\ 2Private Dental Clinic, Çanakkale, Turkey
}

Keywords

Monolithic zirconia, hydrothermal aging, scaling instruments, air-abrasive powder

\section{Anahtar Kelimeler}

Monolitik zirkonya, hidrotermal yaşlanma, kazıma aletleri, aşındırıcı toz

Received/Geliş Tarihi : 05.04.2021

Accepted/Kabul Tarihi : 05.07.2021

doi:10.4274/meandros.galenos.2021.66487

Address for Correspondence/Yazışma Adresi: Habibe Öztürk Ulusoy Ph.D., Çanakkale Onsekiz Mart University Faculty of Dentistry, Department of Prosthodontics, Çanakkale, Turkey

Phone : +90 5058254534

E-mail : habibeozturk@comu.edu.tr

ORCID ID: orcid.org/0000-0002-5985-9421

(C) Meandros Medical and Dental Journal, Published by Galenos Publishing House.

This is article distributed under the terms of the Creative Commons Attribution NonCommercial 4.0

International Licence (CC BY-NC 4.0).

\begin{abstract}
Objective: This study aimed to investigate the effect of hydrothermal aging and various plaque removal methods, which are a part of professional dental cleaning, on zirconia's structural properties.

Materials and Methods: Seventy-two disk-shaped monolithic zirconia specimens (diameter $12 \mathrm{~mm}$ and thickness $1 \mathrm{~mm}$ ) divided into six groups were subjected to no surface treatment, instrumentation with steel curette and ultrasonic steel scaler, and air abrasion with sodium bicarbonate, erythritol, and glycine before being aged in an autoclave at $0.2 \mathrm{MPa}$ and $134{ }^{\circ} \mathrm{C}$ for $2 \mathrm{~h}$. Specimens were analyzed using $\mathrm{X}$-ray diffraction, scanning electron microscopy with energy dispersive $X$-ray spectrometry, and atomic force microscopy to evaluate crystal structure, microstructure, and surface roughness. Further, the contact angle and Vickers hardness measurements were performed for wettability and hardness evaluations. A biaxial bending test was applied to measure the durability of the material.

Results: According to the results, no significant change was found in the crystal structure, surface roughness, and bending strength of zirconia ( $p>0.05)$. In contrast, a substantial decrease in surface hardness values and a significant increase in wettability values were observed in the steel curette and ultrasonic steel scaler groups compared with other groups $(p<0.05)$.

Conclusion: The use of abrasive powders in dental plaque control after prosthetic treatment can help maintain periodontal health and long-term use of prosthesis after restoration of monolithic zirconia.
\end{abstract}

Öz

Amaç: Bu çalışma, profesyonel diş temizliğinin bir parçası olan plak uzaklaştırma yöntemleri ile hidrotermal yaşlanmanın zirkonyanın yapısal özelliklerine etkisini araştırmayı amaçlamıştır.

Gereç ve Yöntemler: Altı gruba bölünmüş 72 adet disk şeklinde monolitik zirkonya örnek (çap $12 \mathrm{~mm}$ ve kalınlık $1 \mathrm{~mm}$ ) otoklavda 0,2 MPa ve $134{ }^{\circ} \mathrm{C}$ 'de 2 saat hidrotermal yaşlandırma öncesi çelik küret, ultrasonik çelik kazıyıcı, sodyum bikarbonat, eritritol ve glisin abraziv toz ile yüzey işlemine tabi tutuldu. Örnekler, kristal yapıyı değerlendirmek için X-ışını kırınımı yöntemi, mikro yapı için taramalı 
elektron mikroskobu ve yüzey pürüzlülüğü için atomik kuvvet mikroskobu kullanılarak analiz edildi. Ayrıca ıslanabilirlik ve sertlik değerlendirmeleri için temas açısı ve Vickers sertlik ölçümleri yapıldı. Malzemenin dayanıklıı̆̆ını ölçmek için ise çift eksenli bükme testi uygulandı.

Bulgular: Sonuçlara göre zirkonyumun kristal yapısında, yüzey pürüzlülüğünde ve eğilme dayanımında önemli bir değişiklik olmadığı görüldü $(p>0,05)$. Çelik küret ve ultrasonik çelik kazıyıcı gruplarında diğer gruplara göre yüzey sertlik değerlerinde önemli düşüş ve ıslanabilirlik değerlerinde anlamlı artış gözlendi $(p<0,05)$.

Sonuç: Monolitik zirkonya restorasyon uygulamasından sonra periodontal sağlığın sürdürülmesi ve protezin uzun süreli kullanımı için protetik tedavi sonrası dental plak kontrolünde aşındırıcı tozlardan faydalanmak uygun bir seçenek olabilir.

\section{Introduction}

The term "monolithic restoration" isn't new for prosthodontic dentistry; namely, they are applied for several years as full ceramic crowns and bridges. Monolithic zirconia systems have increasing demands by both patients and clinicians because of their high esthetic features and durability. Monolithic restorations have been produced from a single piece of highly translucent zirconia through computeraid design/computer-aid manufacturing (CAD/ CAM). While assessing monolithic zirconia's clinical performance, it can be seen that the survival rates are reported between $82.7 \%$ and $100 \%$ for single crown and fixed prosthesis (1).

Zirconia is a polymorphic material, whose structural situation is defined by its mechanical and optical properties. There are three crystalline phases of zirconia in nature at different temperatures: monoclinic $(\mathrm{m})$ form (room temperature-1,170 $\left.{ }^{\circ} \mathrm{C}\right)$, tetragonal (t) form $\left(1,170-2,370{ }^{\circ} \mathrm{C}\right)$, and cubic (c) form (2,370 ${ }^{\circ} \mathrm{C}$-melting point) (2). Crystalline configuration transforms between these phases when the crystalline structure's atomic bonds break apart under different stimuli such as mechanical, thermal, and combined stresses. During the cooling of zirconia from sintering temperature to room temperature, the transformation of $\mathrm{t} \rightarrow \mathrm{m}$ occurs at $\sim 950{ }^{\circ} \mathrm{C}$ spontaneously, known as phase transformation toughening (PTT) $(3,4)$. Throughout transformation, volumetric expansion eventuates within the grains at the monoclinic phase. It contributes to the mechanical strength of the material to some extent, but it should be under control because excessive expansion can give rise to catastrophic failures itself. Some metal oxides such as $\mathrm{CaO}, \mathrm{MgO}, \mathrm{Y}_{2} \mathrm{O}_{3}$, or $\mathrm{CeO}_{2}$ are added to stabilize the $t$ phase of zirconia at room temperature to benefit from PTT clinically (5).

The most commonly used form of zirconia in prosthetic dentistry is the yttria-stabilized $\mathrm{t}$ phase
(Y-TZP) zirconia. It is partially stabilized at room temperature, referred to as metastable state, which means that particular conditions such as humidity, mechanical stress, temperature, surface roughness, can provoke the spontaneous and proceeding transformation of $t \rightarrow m(5)$. Y-TZP is susceptible to a humid environment, even there is no mechanical stress (6). This transformation differs from PTT in terms of the process known as a low-temperature degradation (LTD) phenomenon. So, the LTD process begins with water sorption, then t phase transforms into $m$ phase on the surface and deep into the bulk of Y-TZP as the volume of altered grains increases. This volumetric expansion induces surface uplifts, removing the grains and microcracks, which originate material degradation without mechanical stress (7). As long as this process goes on, microcracks became bigger (8) and finally, fracture strength of Y-TZP decreases due to the transformation of $\% 50$ of the surface crystals (9). When we think about the LTD phenomenon's clinical effects, it comes to mind that it can be crucial for monolithic zirconia restorations to have no porcelain layer so that they immediately interact with saliva which will expedite LTD. Monolithic zirconia has high flexural strength, needs more conservative tooth preparation, gives minimal antagonist wear, displays more satisfying esthetic, saves time both in laboratory and dental procedures (10). More importantly the reason for its popularity is the absence of chipping complications that have been shown to be a high rate of failure concerning the cohesive fracture of veneering ceramic in clinical studies (11).

Preventing inflammatory periodontal disease and/ or dental caries by controlling plaque accumulation as well as prosthodontic treatment quality is vital for a dental prosthesis's long-term survival (12). Plaque control by patients should be carried out regularly to maintain a healthy oral condition and by dentists 
when the patients cannot remove dental plaque in hard-to-reach parts and when there is mineralized dental plaque (calculus) present. It is known that using hand instruments (periodontal curettes) and power-driven instruments (sonic/ultrasonic scaler) for plaque removal is very efficient through intraoral scaling (13). Also, air-powder jet devices enable the removal of dental plaque (14). The scaler tip of the ultrasonic scaler oscillates at about $30 \mathrm{kHz}$ for generating micro-vibrations to elevate dental plaque and calculus under water cooling. Using an ultrasonic scaler provides an advantage of the clinicians in terms of working time and physical effort (15). Therefore, many clinicians widely prefer spending more time on ultrasonic scaling than hand instrumentation for tooth cleaning in dental offices. But instrumentations with Gracey curette and ultrasonic scaler causes unwanted effects like disturbance, pain and defects on dental material (16). In such a case, air-powder polishing systems utilizing pressurized air, water and an abrasive powder can be a less unpleasant, easy and quick option (14). The first air powder application was sodium bicarbonate, a very abrasive material (17). Less abrasive powders such as glycine and erythritol have been developed to eliminate the detrimental effect of sodium bicarbonate over soft and hard tissues and restorative material's surfaces (18).

Once after the prosthetic treatment, especially for a fixed prosthesis, plaque accumulation should be monitored carefully at regular intervals. So, plaque formation can begin for the first year of a prosthesis and affect the abutment teeth (19). Thus, prosthodontic restorations may be exposed to different mechanical plaque control methods and their effects repeatedly. As a result, mechanical surface treatment and LTD may induce the sensitivity to degradation of monolithic zirconia's structural features and clinical fractures (20). The tested hypothesis in this study was that surface treatments stem from different plaque control methods and LTD does not generate any differences in the structural properties of monolithic zirconia. Crystalline structure, micro-hardness, surface roughness, wettability, fracture strength and microstructure of monolithic zirconia were analyzed through the present study to investigate whether or not periodontal surface treatment methods affect the material.

\section{Materials and Methods}

Preparation of Specimens and Surface Treatments

Seventy-two disc-shaped specimens $(12 \mathrm{~mm}$ in diameter, $1 \mathrm{~mm}$ thick) of monolithic zirconia were milled out from pre-sintered 3Y-TZP blanks (Nacera Pearl 1, Doceram, Dortmund, Germany) by a CAD/ CAM system according to DIN EN ISO 6872:2019 (21). The specimens sintered at $1,450{ }^{\circ} \mathrm{C}$ for $2 \mathrm{~h}$, according to the manufacturer's instructions were divided into six groups $(n=12)$ related to specified treatment after sintering; group 1: untreated control (C), group 2: scaling by a steel curette (H6/H7 DE Scaler, Hu-Friedy, Chicago, USA) (Sc), group 3: scaling by ultrasonic scaler with a steel tip (Cavitron, Dentsply Sirona, Charlotte, USA) (USc), group 4: air-polishing with sodium bicarbonate powder ( $\mathrm{Na})$, group 5: air-polishing with erythritol powder (Er), group 6: air-polishing with glycine powder (GI). All specimens except the untreated control group were autoclaved to perform the LTD phenomenon. The conditions of accelerating the aging test in an autoclave (Andromeda Vacuum XP, Tecno-Gaz S.p.A., Parma, Italy) were determined according to the previous study (22). The specimens were exposed to autoclaving for $2 \mathrm{~h}$ at $134^{\circ} \mathrm{C}$ and 0.2 MPa.

Surface treatment procedures were performed by a particular operator with at least 10 years of clinical experience as a periodontal specialist to standardize the instrumentations. Scaling with a steel curette was made by five strokes and 10 times in the same direction and location. Blades were contacted to the zirconia surface at an angulation of 70 degrees $(23,24)$. The ultrasonic scaler with a steel tip was utilized for $1 \mathrm{~min}$ and repeated 10 times under water cooling. The ultrasonic scaler tip was placed on the zirconia surface to contact its lateral surface with an inclination of almost 0 degrees. Scaling motions were executed all over the surface of the specimens briefly, continuously, and equally in the same direction (25). Powders were applied using the standard unit (Air-Flow Master, EMS SA, Switzerland) by the same periodontal specialist. For air-polishing treatment, a nozzle of the air-polishing device was located $5 \mathrm{~mm}$ away at a $90^{\circ}$ angle to the surface of the zirconia specimen (26). In clinical situations, the nozzle is moved usually during spraying and powder doesn't affect a particular area for the presumed treatment 
time. Therefore, it was decided that air-polishing procedures were performed for 10 seconds at a pressure of 1.8 bar. Before autoclaving, the specimens with different surface treatments were ultrasonically cleaned in pure water for $5 \mathrm{~min}$.

\section{Assessment of Structural Properties}

Crystalline Structure Analysis-X-ray Diffractometer

$\mathrm{X}$-ray diffractometer (XRD) analysis was carried out to detect the amount of tetragonal and monoclinic phases on the surface of a specimen for each group zirconia. Monolithic zirconia specimens were selected randomly from each group. We used a diffractometer (Empyrean, Malvern Panalytical Ltd, United Kingdom) using CuK $\alpha$ radiation recorded within the range of $20^{\circ}-80^{\circ}$, a step size of $0.04^{\circ}$ and a scanning time per step of $10 \mathrm{sec}$ at $40 \mathrm{kV}$ and $40 \mathrm{~mA}$ to analyze the specimens. According to this, Im (-111) monoclinic peak intensity is around $28.2^{\circ} 2 \theta, \mathrm{Im}(111)$ monoclinic peak intensity is around $31.5^{\circ}, 2 \theta$, and the It (101) tetragonal peak intensity is around $30.2^{\circ}, 2 \theta$. The ratio of the monoclinic phase $(\mathrm{Xm})$ at the surfaces of zirconia was calculated using the formula below (32):

$\mathrm{Xm}=[\operatorname{Im}(-111)+\operatorname{Im}(111)] /[\operatorname{Im}(-111)+\operatorname{Im}(111)$ + It ( 101) ]

The volume ratio of the monoclinic and tetragonal phase was calculated according to Toraya et al. (27) by using the following formula.

$\mathrm{Vm}=1.311 \mathrm{Xm} /(1+0.311 \mathrm{Xm})$

$\mathrm{Xm}$ : Complete intensity of monoclinic phase, $\mathrm{Vm}$ : Monoclinic phase volume ratio.

\section{Surface Roughness}

The surface roughness of zirconia specimens was evaluated using an atomic force microscope (AFM) (Alpha 3100R, WITec, Ulm, Germany). During the surface analysis, three specimens were randomly selected from each group to determine surface roughness profile values ( $\mathrm{Ra}$ ), and a $5 \times 5 \mathrm{~mm}$ area on the specimen was scanned at $0.1 \mathrm{~Hz}$ and observed for cracks, etc. This procedure was repeated 3 times on each specimen and a mean Ra was specified for the specimen to identify the roughness of the zirconia surface.

\section{Biaxial Bending Test}

To the biaxial flexural strength test, we used piston on three-ball method through a universal test machine (Mts Ceriterion model 42, MTS Systems Corporation, USA) with an apparatus that was specially produced for this test according to ISO 6872 and mounted on the upper and lower supportive arms of the test machine at head-speed of $1 \mathrm{~mm} / \mathrm{min}$. There were three steel balls with a diameter of $2.5 \mathrm{~mm}$ in the lower part of the apparatus, and they were positioned $120^{\circ}$ with each other. A flat punch of $1.4 \mathrm{~mm}$ diameter in the upper part of this apparatus applied pressure to the center of the zirconia specimen with a cross speed of $1 \mathrm{~mm} / \mathrm{min}$ to the point of fracture.

A computer connected to the testing machine recorded the force when fracturing eleven specimens for each zirconia group. It converted the test results from $\mathrm{N}$ to $\mathrm{MPa}$ according to the international standards (ISO 6872) using the following formula;

$S=-0,2387 P(X-Y) / d^{2}$

$\mathrm{S}$ : Maximum center tensile stress ( $\mathrm{MPa}), \mathrm{P}$ : Total load causing fracture $(\mathrm{N})$

$X=(1+V) \ln (r 2 / r 3)^{2}+[(1-V) / 2](r 2 / r 3)^{2}, Y=(1+V)[1+$ $\left.\ln (r 1 / r 3)^{2}\right]+(1-V)(r 1 / r 3)^{2}$

$(v)$ : Poisson ratio (We took ' $V$ ' as 0.25 which should be used if the value is unknown in this study.) $r 1$ : Radius of the support circle $(\mathrm{mm}), \mathrm{r} 2$ : Radius of the loaded area $(\mathrm{mm}), \mathrm{r} 3$ : Radius of the specimen $(\mathrm{mm})$, $\mathrm{d}$ : Thickness of the specimen at fracture origin $(\mathrm{mm})$.

\section{Microstructure Analysis}

After the biaxial bending test, a specimen for each group was observed by field emission scanning electron microscope (FE-SEM) (Jeol SEM-7100-EDX, The Netherlands). For the FE-SEM characterization, the images were taken at a magnification of $x 500$. The chemical composition of monolithic zirconia and amount of stabilizer $\mathrm{Y}_{2} \mathrm{O}_{3}, \mathrm{HfO}_{2}$ and $\mathrm{ZrO}_{2}$ on the surface were analyzed using energy-dispersive $\mathrm{X}$-ray spectrometry (EDX) to evaluate whether there is a quantitative change due to the surface treatments.

\section{Wettability}

Pure water was dripped via a micro syringe on the surface of a specimen for each group zirconia to evaluate the contact between liquid and surface of the specimen. When a droplet touched the surface, a contact angle meter (CA-X; Kyowa Interface Science, Saitama, Japan) measured the contact angle of the droplet within $5 \mathrm{sec}$.

\section{Measurement of Vickers Micro-hardness Value}

A micro-hardness device (Shimadzu HMV-G, Japan) was used to measure the hardness of the specimens. After the biaxial bending test, all zirconia specimens were fixed to the testing device and $1 \mathrm{~kg}(9.8 \mathrm{~N})$ force 
with a speed of $0.015-0.07 \mathrm{~mm} / \mathrm{sec}$. A diagonal notch was created on the surface of the zirconia, then the notch was measured employing a microscope attached to the device. Micro-hardness values (HV) were calculated via the device's software using the following formula:

$H V=1.8544\left(P / d^{2}\right)$

$P$ : Load (kgf), d: The average length of the two diagonal lines of the notch $(\mathrm{mm})$.

\section{Statistical Analysis}

Data were analyzed with SPSS V23 (IBM, New York, USA). Shapiro-Wilk examined compliance with a normal distribution. One-Way ANOVA was used for comparisons according to groups. Multiple comparisons were analyzed using the Tukey HSD test. Data are presented as mean \pm standard deviation. The level of significance was taken as $p<0.05$.

\section{Results}

\section{Crystalline Structure Analysis-XRD}

$X$-ray diffractograms of all groups are shown in Figure 1. XRD patterns of monolithic zirconia are similar in all groups. A quantitative comparison showed that surface treatments did not affect the

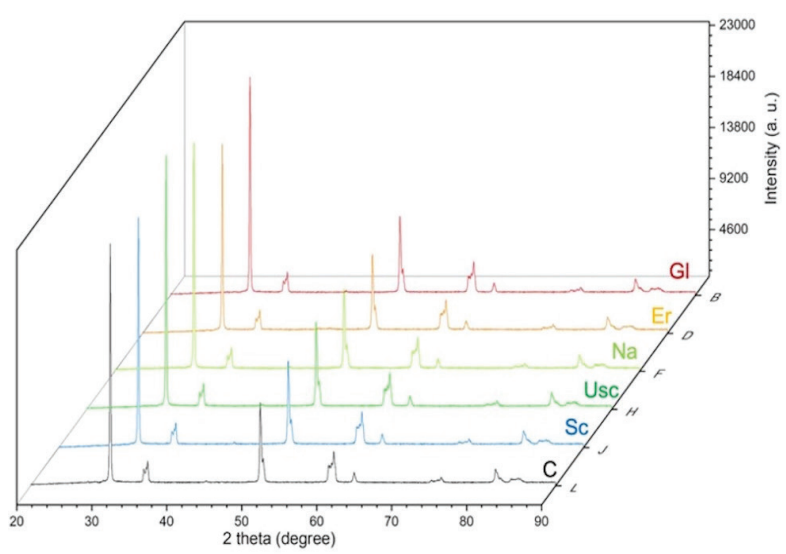

Figure 1. Representative X-ray diffractometer spectrum of monolithic zirconia specimens with different surface treatment. a. Control group. b. Scaler group. c. Ultrasonic scaler group. d. Sodium bicarbonate powder group. e. Erythritol powder group. f. Glycine powder group peak intensities of $\operatorname{Im}(-111)$ and Im (111) after calculating the monoclinic fraction (Table 1).

\section{Surface Roughness}

Although there was no significant difference between the Ra values of the surface-treated samples ( $p>0.05)$, it was seen that the specimens in the USc group had rougher surfaces according to the threedimensional AFM images obtained. The $\mathrm{C}$ group samples show that the roughness is less than the treated surfaces (Figure 2).

\section{Biaxial Bending Test}

Biaxial bending strength ranged from $366.6 \mathrm{MPa}$ (Sc) to $301.7 \mathrm{MPa}(\mathrm{Na})$. Surface treatments applied had no significant effect on zirconia specimens' bending strength $(p>0.05)$. The biaxial bending strength values of monolithic zirconia samples are shown in Table 2.

\section{FE-SEM and EDX Evaluation}

Microscopic observation showed that the surface of the monolithic zirconia disc was not much affected by different surface treatments in Figure 3 . It is seen that there is no quantitative change of $\mathrm{Y}, \mathrm{Hf}$ and $\mathrm{Zr}$ percentages by weight on the surface after different surface treatments. EDX findings are shown in Table 3.
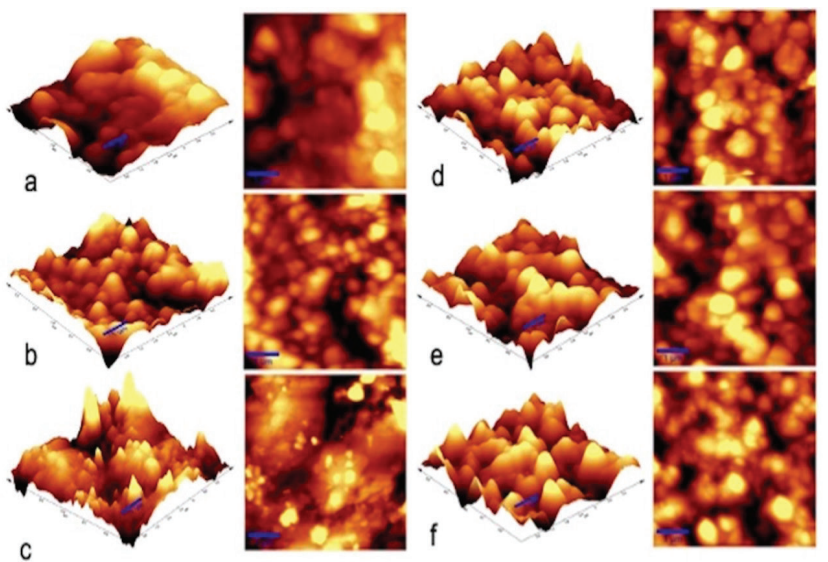

Figure 2. Representative three-dimensional atomic force microscope topographic images of all groups. a. Control group. b. Scaler group. c. Ultrasonic scaler group. d. Sodium bicarbonate powder group. e. Erythritol powder group. f. Glycine powder group

Table 1. Quantitative data related to monoclinic phase volumes of the groups measured by XRD (Vm, \%)

\begin{tabular}{|l|l|l|l|l|l|l|}
\hline & C & Sc & USc & Na & Er & GI \\
\hline Xm & 0.6029 & 0.60873 & 0.6146 & 0.60232 & 0.59295 & 0.6256 \\
\hline Vm & 0.6656 & 0.67101 & 0.67645 & 0.66506 & 0.65633 & 0.68658 \\
\hline
\end{tabular}




\section{Wettability}

The contact angle value varies according to the groups $(p<0.05)$. Accordingly, the contact angle in the USc $\left(26.3^{\circ}\right)$ was obtained the lowest, while the $C$ group was the highest $\left(80.5^{\circ}\right)$. Group $C$ is different according to all groups statistically. There was no difference between the $\mathrm{Na}, \mathrm{Er}$ and $\mathrm{Gl}$ groups; $46^{\circ}, 62^{\circ}$ and $58^{\circ}$ ( $p>0.05$ ). The results of contact angle measurements are summarized in Figure 4.

\section{Vickers Micro-hardness Values}

Vickers micro-HVs of monolithic zirconia specimens are shown in Table 2. Vickers values analyzed by One-

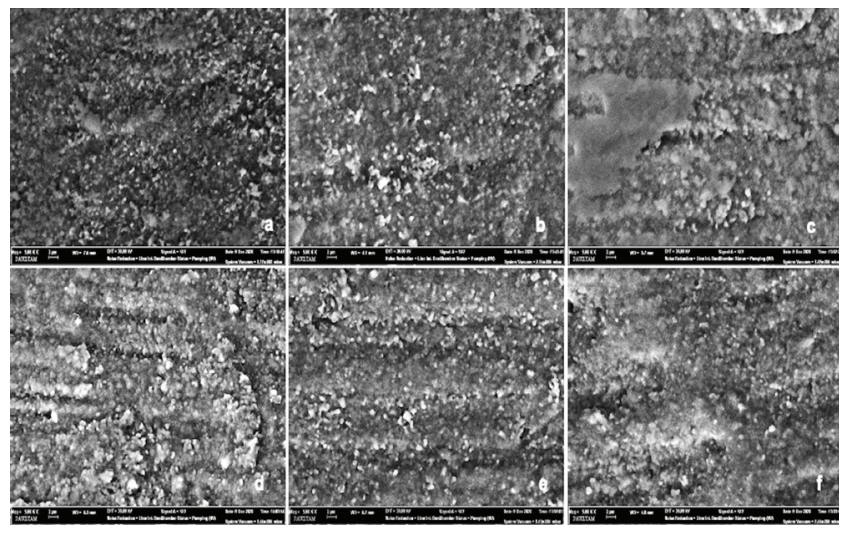

Figure 3. Representative images of scanning electron microscope analysis at 500x of monolithic zirconia disc a. Control group. b. Scaler group. c. Ultrasonic scaler group. d. Sodium bicarbonate powder group. e. Erythritol powder group. f. Glycine powder group
Way ANOVA showed significant differences among groups $(p<0.05)$. Sc and USc groups were significantly lower than the other groups, $1232.6 \pm 86.2$ and 1109.7 $\pm 45.5 \mathrm{MPa}$.

\section{Discussion}

The present study was designed to examine the effect of repeatedly using different plaque removal methods and hydrothermal aging on monolithic zirconia's structural properties. According to the study's findings, we accepted the hypothesis that plaque removal methods and thermal aging would

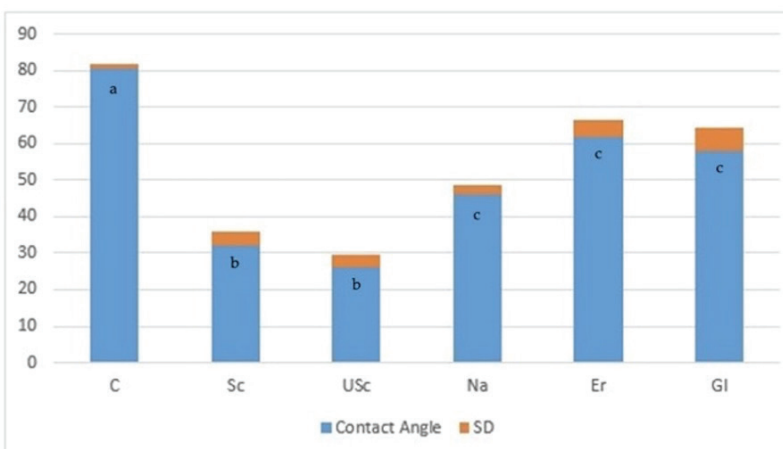

Figure 4. Contact angle of a pure water droplet on the monolithic zirconia subjected to different surface treatments. a. Control group. b. Scaler group. c. Ultrasonic scaler group. d. Sodium bicarbonate powder group. e. Erythritol powder group. f. Glycine powder group

SD: Standard deviation

\begin{tabular}{|c|c|c|c|}
\hline Group & Vickers mean \pm SD (MPa) & Ra mean \pm SD $(\mathrm{nm})$ & Biaxial mean \pm SD (MPa) \\
\hline C & $1473.8 \pm 44.2^{\mathrm{a}}$ & $136.1 \pm 29.9$ & $329.2 \pm 125.7$ \\
\hline Sc & $1232.6 \pm 86.2^{b}$ & $175.3 \pm 15.2$ & $366.6 \pm 133.7$ \\
\hline USC & $1109.7 \pm 45.5^{c}$ & $182.12 \pm 40.2$ & $336.2 \pm 135.1$ \\
\hline $\mathrm{Na}$ & $1311.5 \pm 20.5^{a}$ & $166.2 \pm 70.6$ & $301.7 \pm 94.4$ \\
\hline $\mathrm{Er}$ & $1387.5 \pm 31^{\text {a }}$ & $142.9 \pm 29.2$ & $303.4 \pm 93.8$ \\
\hline $\mathrm{Gl}$ & $1291.9 \pm 127.4^{\mathrm{a}}$ & $142.9 \pm 29.2$ & $316.5 \pm 100.7$ \\
\hline
\end{tabular}

\begin{tabular}{|c|c|c|c|c|c|c|}
\hline & C & Sc & USc & $\mathrm{Na}$ & Er & GI \\
\hline Y & 2.73 & 2.37 & 2.78 & 2.42 & 2.50 & 2.49 \\
\hline $\mathrm{Hf}$ & 1.45 & 1.31 & 1.24 & 1.18 & 1.19 & 1.18 \\
\hline $\mathrm{Zr}$ & 79.63 & 70.88 & 71.11 & 71.1 & 73.34 & 72.04 \\
\hline
\end{tabular}


not cause any changes in the determinants examined to predict the behavior of zirconia.

Dental plaque is accepted as the main etiological factor in the pathogenesis of periodontal diseases (28). Rough surfaces in the mouth have an essential effect on plaque formation. Because microorganisms primarily adhere to areas with surface irregularities (29). Dental plaque can accumulate on the surface of the restorative material as well as on the tooth surface. Some surface properties of the restorative material, such as the material's chemical structure, surface roughness, surface topography, and ion release can strongly affect plaque formation and bacterial adhesion (30). Dental plaque control emerges as an essential factor in preventing periodontal diseases (31). In this study, we simulated plaque control procedures performed by the dentist at least every six months after prosthetic treatment (32).

In our study, AFM analysis shows no significant difference between the different surface treatments applied for plaque control and aging in terms of surface roughness values ( $\mathrm{Ra})$. Our findings regarding the effect of Sc and USC on roughness $(175.3 \pm 15.2$ $\mathrm{nm}$ and $182.12 \pm 40.2 \mathrm{~nm}$ ) are consistent with other studies. The previous research observed by Lee et al. (33) to investigate the optical properties and surface roughness of different restorative materials has shown that ultrasonic scaling with steel tip does not cause any changes on the surface roughness of zirconia. Another study examining bacterial adhesion on varied restorative materials after plaque removal via scaling both steel curette and ultrasonic scaler points to scalers did not affect zirconia surface roughness (34). In contrast to the present study, Nakazawa et al. (25) reported that ultrasonic scaling increases the surface roughness with or without aging. They observed that small pits were formed on the zirconia surface instead of scratches, and they concluded that this occurred due to particle break off from the surface due to LTD. Vigolo, too, examined the effect of steel and titanium curettes on zirconia and lithium disilicate surfaces and concluded that the steel curette increased the zirconia surface roughness (35). Methodological differences like instrumentation time, pressure and operator's skill in the surface treatment may explain the variability of results among so-called studies. Previous studies investigating the effect of air-abrasive powders on teeth and dental materials showed that sodium bicarbonate powder increases the roughness of tooth and composite surfaces. Glycine and erythritol also have surface changing effects, but they are less abrasive $(26,36,37)$. Glycine powder causes the least surface damage during the removal of plaque on different restorative materials (38). Although the Ra values are higher in the $\mathrm{Na}$, $\mathrm{Er}$ and $\mathrm{Gl}$ groups $(166.2 \pm 70.6 \mathrm{~nm}, 142.9 \pm 29.2 \mathrm{~nm}$ and $142.9 \pm 29.2 \mathrm{~nm}$, respectively) than the $C$ group $(136.1 \pm 29.9 \mathrm{~nm})$ in our study, air-abrasive powders do not affect the roughness of the material owing to zirconia's surface hardness that is higher than the abrasive particles used.

In this study, a piston-on-three-ball test applied for biaxial bending strength to simulate pure bending and prevent edge loss. It is less sensitive than uniaxial tests such as 3-point or 4-point bending tests to the undetectable defect of the material ata loaded position. In addition, its easy use resulted in fewer errors than other tests and provided clinically adaptable results (39). The results show that biaxial bending strength of zirconia is not affected by the surface treatments and aging effects $(p>0.05)$. Although different aging and different abrasive powders are used, there are studies in the literature that are compatible with our study results $(40,41)$. Moqbel et al. (42) detected an increase in biaxial flexural strength of zirconia after aging and surface treatment with alumina particle and polishing. They explained the different results by hardening strength caused by compressive stresses during monoclinic phase transformation increased the amount of force required to break the samples. In this study, no significant difference was observed between the flexural strength results due to $t \rightarrow m$ phase transformation on the zirconia surface was lower and the diameter, hardness, and application pressures of the abrasive powders used were different from previous research.

Zirconia is composed of different crystal phases. The $t$ phase determines the mechanical properties of the material at room temperature (43). $t \rightarrow m$ phase transformation caused by dental stresses such as etching, sandblasting, and hydrothermal aging (LTD) causes deterioration of zirconia's superior mechanical properties (42). LTD is time-dependent phenomenon and aging time is affecting $t \rightarrow m$ phase transformation. The current aging process of the zirconia specimens to simulate the LTD effect in this in-vitro study depends 
on a previous study by Chevalier et al. (22). Chevalier stated that one hour of autoclave treatment at 134 ${ }^{\circ} \mathrm{C}$ and 2 bar (0.2 MPa) pressure had theoretically corresponded to a similar effect as 3-4 years aging at $37^{\circ} \mathrm{C}$ in the oral environment.

During the $\mathrm{m}$ phase transformation due to mechanical stress, the compression pressure created by the volumetric expansion of the particles increases the durability of the material by preventing the cracks' progress on the surface (44). Without mechanical stress, the $m$ phase transformation based on humidity and temperature occurs slowly in the particles contact with water. Meantime, a progressive process occurs that causes the mechanical properties of the material to deteriorate with a rise in the surface, followed by microfracture and pull-out of the particle on the surface $(6,45)$. Studies have not fully understood the effect of LTD on the mechanical properties of zirconia. So much so that studies are showing that it affects mechanical properties positively and studies showing that it does not affect $t \rightarrow m$ phase transformation $(42,46,47)$. Our phase transformation results analyzed utilizing an XRD show that aging and different surface treatments do not significantly impact $\mathrm{t} \rightarrow \mathrm{m}$ phase transformation since the two-hour aging period in our study may not have increased the activation energy for the tetragonal to monoclinic transformation on the zirconia surface. A previous study investigating the effect of ultrasonic scaling and LTD on phase transformation stated that ultrasonic scalers did not affect the phase transformation on the zirconia surface. But independent of the ultrasonic scaling processes, LTD increased the $t \rightarrow m$ phase transformation and decreased the material's surface hardness (25). Although our findings are partially compatible with the study mentioned above, the phase transformation percentages differed from ours due to the extended aging time for LTD. Sc and USc groups indicated lower surface hardness results, but there were no important changes in the other groups. Micro-fractures occurring on the surface during scaling may have caused transformation hardening on the surface. This discrepancy might be an artifact of measurement that linked to the manufacturing process causing micro-notches. It might be thought that these notches make it challenging to evaluate hardness test results.

While investigating the phase transformation on the surface of monolithic zirconia, evaluating the changes in the amount of stabilizers $\left(\mathrm{Y}_{2} \mathrm{O}_{3}, \mathrm{HfO}_{2}\right.$, and $\mathrm{ZrO}_{2}$ ) can provide useful information. Some studies have reported an increase in the $\mathrm{Y}_{2} \mathrm{O}_{3}$ ratio on the surface decreases $t \rightarrow m$ phase transformation arise as an effect of aging (48). Research on LTD effects said that $Y$ concentration on zirconia surface decreased and Y-TZP structure weakened when they are kept in a humid environment (49). $\mathrm{Y}$ and $\mathrm{Hf}$ ratios by virtue of EDX analysis in surface treatment groups kept up with the $C$ group in this study. The findings show no stabilizer loss, so there is no phase transformation on the material surface as presented by XRD analysis.

Biofilm formation over dental materials in the mouth is related to the surface roughness, wettability, and the interaction of bacteria with the surface (50). John et al. (51) reported that hydrophilicity is a more significant factor than surface roughness for dental plaque accumulation. Regarding the effects of different surface treatments, we detected substantial change in the wettability of monolithic zirconia. The most hydrophobic group was the non-treated $C$ group, with a contact angle of $80.5^{\circ}$. The hydrophilic properties of zirconia specimens in Sc and USc groups (contact angle $26.3^{\circ}$ and $32^{\circ}$ ) increased after different surface treatments. The air-abrasive powders caused decrease in the contact angle compatible with previous research studied by Sturz et al. (52). A previous study informed that hydrophilicity could increase only with LTD. Besides, they said that LTD and surface treatment with ultrasonic scaling using a steel tip caused hydrophobic surface. Because of the aging time in that study, LTD may stimulate to release of hydroxyl groups due to the degradation of $\mathrm{Zr}-\mathrm{O}-\mathrm{Zr}$ bonds that specify the hydrophilicity may have been removed from the surface during ultrasonic scaling (25).

The limitation of this in-vitro study is that only the thermal conditions were applied similar to the oral environment were evaluated. Still, mechanical loading is a factor that did not assess in the present study. Although the current study showed promising results about the usage of air-abrasive powders to professional plaque control after prosthetic treatment for monolithic zirconia restoration, the structural behavior of this zirconia needs to be investigated under thermal and mechanical loading in the aqueous environment. Therefore, further studies should be considered to address these issues before definitive conclusions can be drawn. 


\section{Conclusion}

Considering the results of our study, using airabrasive powders for professional plaque control in the supportive treatment maintaining post-prosthetic periodontal health may be an appropriate treatment for monolithic zirconia restorations.

\section{Ethics}

Ethics Committee Approval: This study does not require ethics committee approval.

Informed Consent: This study does not require informed consent.

Peer-review: Internally peer-reviewed.

\section{Authorship Contributions}

Concept: H.Ö.U., Design: H.Ö.U., Ç.A., Supervision: H.Ö.U., Ç.A., Fundings: H.Ö.U., Materials: H.Ö.U., Data Collection or Processing: H.Ö.U., C..A., Analysis or Interpretation: H.Ö.U., Literature Search: H.Ö.U., Writing: H.Ö.U., Ç.A., Critical Review: H.Ö.U., Ç.A.

Conflict of Interest: No conflict of interest was declared by the authors.

Financial Disclosure: This research was funded by Scientific Research Commission of Çanakkale Onsekiz Mart University (Project no: TSA-2019-3055).

\section{References}

1. Kontonasaki E, Rigos AE, Ilia C, Istantsos T. Monolithic Zirconia: An Update to Current Knowledge. Optical Properties, Wear, and Clinical Performance. Dent J (Basel) 2019; 7: 90.

2. Kisi E, Howard C. Crystal structures of zirconia phases and their interrelation. Key Eng Mater 1998; 153/154: 1-35.

3. Garvie RC, Nicholson PS. Phase analysis in zirconia systems. Journal of the American Ceramic Society 1972; 55: 303-5.

4. Kelly JR. Dental ceramics: current thinking and trends. Dent Clin North Am 2004; 48: viii, 513-30.

5. Zarone F, Di Mauro MI, Ausiello P, Ruggiero G, Sorrentino R. Current status on lithium disilicate and zirconia: a narrative review. BMC Oral Health 2019; 19: 134.

6. Chevalier J, Cales B, Drouin JM. Low-temperature aging of Y-TZP ceramics. Journal of the American Ceramic Society 1999; 82: 2150-4.

7. Kontonasaki E, Giasimakopoulos P, Rigos AE. Strength and aging resistance of monolithic zirconia: an update to current knowledge. Jpn Dent Sci Rev 2020; 56: 1-23.

8. Lee JK, Kim H. Surface crack initiation in 2Y-TZP ceramics by lowtemperature aging. Ceram Int 1994; 20: 413-8.

9. Kim HT, Han JS, Yang JH, Lee JB, Kim SH. The effect of low temperature aging on the mechanical property \& phase stability of Y-TZP ceramics. J Adv Prosthodont 2009; 1: 113-7.

10. Griffin JD Jr. Combining monolithic zirconia crowns, digital impressioning, and regenerative cement for a predictable restorative alternative to PFM. Compend Contin Educ Dent 2013; 34: 212-22.

11. Sulaiman TA, Abdulmajeed AA, Delgado A, Donovan TE. Fracture rate of 188695 lithium disilicate and zirconia ceramic restorations after up to 7.5 years of clinical service: A dental laboratory survey. J Prosthet Dent 2020; 123: 807-10.

12. Axelsson $P$, Nyström $B$, Lindhe J. The long-term effect of a plaque control program on tooth mortality, caries and periodontal disease in adults. Results after 30 years of maintenance. J Clin Periodontol 2004; 31: 749-57.

13. Walmsley $A D$, Lea $S C$, Landini G, Moses AJ. Advances in power driven pocket/root instrumentation. J Clin Periodontol 2008; 35(8 Suppl): 22-8.

14. Bühler J, Amato $M$, Weiger R, Walter C. A systematic review on the patient perception of periodontal treatment using air polishing devices. Int J Dent Hyg 2016; 14: 4-14.

15. Kocher T, Rühling A, Momsen $H$, Plagmann HC. Effectiveness of subgingival instrumentation with power-driven instruments in the hands of experienced and inexperienced operators. A study on manikins. J Clin Periodontol 1997; 24: 498-504.

16. Canakçi CF, Canakçi V. Pain experienced by patients undergoing different periodontal therapies. J Am Dent Assoc 2007; 138: 1563-73.

17. BLACK RB. Airbrasive: some fundamentals. J Am Dent Assoc 1950; 41: 701-10.

18. Barnes CM, Covey D, Watanabe H, Simetich B, Schulte JR, Chen $\mathrm{H}$. An in vitro comparison of the effects of various air polishing powders on enamel and selected esthetic restorative materials. J Clin Dent 2014; 25: 76-87.

19. Al-Sinaidi A, Preethanath RS. The effect of fixed partial dentures on periodontal status of abutment teeth. The Saudi Journal for Dental Research 2014; 5: 104-8.

20. Reich S, Petschelt A, Lohbauer $U$. The effect of finish line preparation and layer thickness on the failure load and fractography of ZrO2 copings. J Prosthet Dent 2008; 99: 369-76.

21. DIN EN ISO 6872:2019 Dentistry-ceramic materials, International Organization for Standardization, Geneva, Switzerland (2019).

22. Chevalier J, Loh J, Gremillard L, Meille S, Adolfson E. Lowtemperature degradation in zirconia with a porous surface. Acta Biomater 2011; 7: 2986-93.

23. Vigolo $\mathrm{P}$, Motterle $\mathrm{M}$. An in vitro evaluation of zirconia surface roughness caused by different scaling methods. J Prosthet Dent 2010; 103: 283-7.

24. Ota-Tsuzuki C, Martins FL, Giorgetti AP, de Freitas PM, Duarte PM. In vitro adhesion of Streptococcus sanguinis to dentine root surface after treatment with Er:YAG laser, ultrasonic system, or manual curette. Photomed Laser Surg 2009; 27: 735-41.

25. Nakazawa K, Nakamura K, Harada A, Shirato M, Inagaki R, Örtengren $U$, et al. Surface properties of dental zirconia ceramics affected by ultrasonic scaling and low-temperature degradation. PLoS One 2018; 13: e0203849.

26. Bühler J, Schmidli F, Weiger R, Walter C. Analysis of the effects of air polishing powders containing sodium bicarbonate and glycine on human teeth. Clin Oral Investig 2015; 19: 877-85. 
27. Toraya H, Yoshimura M, Somiya S. Calibration Curve for Quantitative Analysis of the Monoclinic-Tetragonal ZrO2 System by X-Ray Diffraction. Journal of the American Ceramic Society 1984; 67: 119-21.

28. Lang NP, Schätzle MA, Löe H. Gingivitis as a risk factor in periodontal disease. J Clin Periodontol 2009; 36 Suppl 10: 3-8.

29. Rashid $H$. The effect of surface roughness on ceramics used in dentistry: A review of literature. Eur J Dent 2014; 8: 571-9.

30. Hao $Y$, Huang $X$, Zhou $X$, Li M, Ren B, Peng $X$, et al. Influence of Dental Prosthesis and Restorative Materials Interface on Oral Biofilms. Int J Mol Sci 2018; 19: 3157.

31. Lamont T, Worthington HV, Clarkson JE, Beirne PV. Routine scale and polish for periodontal health in adults. Cochrane Database Syst Rev 2018; 12: CD004625.

32. Rosén B, Olavi G, Badersten A, Rönström A, Söderholm G, Egelberg J. Effect of different frequencies of preventive maintenance treatment on periodontal conditions. 5-Year observations in general dentistry patients. J Clin Periodontol 1999; 26: 225-33.

33. Lee JH, Kim SH, Han JS, Yeo ISL, Yoon HI, Lee J. Effects of ultrasonic scaling on the optical properties and surface characteristics of highly translucent CAD/CAM ceramic restorative materials: An in vitro study. Ceramics International 2019; 45: 14594-601.

34. Checketts MR, Turkyilmaz I, Asar NV. An investigation of the effect of scaling-induced surface roughness on bacterial adhesion in common fixed dental restorative materials. J Prosthet Dent 2014; 112: 1265-70.

35. Vigolo P, Buzzo O, Buzzo M, Mutinelli S. An In Vitro Evaluation of Alumina, Zirconia, and Lithium Disilicate Surface Roughness Caused by Two Scaling Instruments. J Prosthodont 2017; 26: 129-35.

36. Giacomelli L, Salerno M, Derchi G, Genovesi A, Paganin PP, Covani U. Effect of air polishing with glycine and bicarbonate powders on a nanocomposite used in dental restorations: an in vitro study. Int J Periodontics Restorative Dent 2011; 31: e51-6.

37. Janiszewska-Olszowska J, Drozdzik A, Tandecka K, Grocholewicz $K$. Effect of air-polishing on surface roughness of composite dental restorative material - comparison of three different airpolishing powders. BMC Oral Health 2020; 20: 30.

38. Cobb CM, Daubert DM, Davis K, Deming J, Flemmig TF, Pattison $A$, et al. Consensus Conference Findings on Supragingival and Subgingival Air Polishing. Compend Contin Educ Dent 2017; 38: e1-4.
39. Chantranikul N, Salimee P. Biaxial flexural strength of bilayered zirconia using various veneering ceramics. J Adv Prosthodont 2015; 7: 358-67.

40. Egilmez F, Ergun G, Cekic-Nagas I, Vallittu PK, Lassila LV. Factors affecting the mechanical behavior of Y-TZP. J Mech Behav Biomed Mater 2014; 37: 78-87.

41. Pereira GKR, Muller C, Wandscher VF, Rippe MP, Kleverlaan CJ, Valandro LF. Comparison of different low-temperature aging protocols: its effects on the mechanical behavior of Y-TZP ceramics. J Mech Behav Biomed Mater 2016; 60: 324-30.

42. Moqbel NM, Al-Akhali M, Wille S, Kern M. Influence of Aging on Biaxial Flexural Strength and Hardness of Translucent 3Y-TZP. Materials (Basel) 2019; 13: 27.

43. Piconi C, Maccauro G. Zirconia as a ceramic biomaterial. Biomaterials 1999; 20: 1-25.

44. Kelly PM, Ball CJ. Crystallography of stress-induced martensitic transformations in partially stabilized zirconia. Journal of the American Ceramic Society 1986; 69: 259-64.

45. Fischer $H$, Schäfer $M$, Marx R. Effect of surface roughness on flexural strength of veneer ceramics. J Dent Res 2003; 82: 972-5.

46. Pereira G, Amaral M, Cesar PF, Bottino MC, Kleverlaan CJ, Valandro LF. Effect of low-temperature aging on the mechanical behavior of ground Y-TZP. J Mech Behav Biomed Mater 2015; 45: 183-92.

47. Pereira GKR, Muller C, Wandscher VF, Rippe MP, Kleverlaan CJ, Valandro LF. Comparison of different low-temperature aging protocols: its effects on the mechanical behavior of Y-TZP ceramics. J Mech Behav Biomed Mater 2016; 60: 324-30.

48. Lawson S. Environmental degradation of zirconia ceramics. Journal of the European Ceramic Society 1995; 15: 485-502.

49. Kasemo B, Gold J. Implant surfaces and interface processes. Adv Dent Res 1999; 13: 8-20.

50. Nabert-Georgi C, Rodloff AC, Jentsch H, Reissmann DR, Schaumann R, Stingu CS. Influence of oral bacteria on adhesion of Streptococcus mutans and Streptococcus sanguinis to dental materials. Clin Exp Dent Res 2018; 4: 72-7.

51. John G, Becker J, Schwarz F. Effects of different titanium zirconium implant surfaces on initial supragingival plaque formation. Clin Oral Implants Res 2017; 28: e84-e90.

52. Sturz CR, Faber FJ, Scheer M, Rothamel D, Neugebauer J. Effects of various chair-side surface treatment methods on dental restorative materials with respect to contact angles and surface roughness. Dent Mater J 2015; 34: 796-813. 